

\section{DISCLAIMER}

This report was prepared as an account of work sponsored by an agency of the United States Government. Neither the United States Government nor any agency Thereof, nor any of their employees, makes any warranty, express or implied, or assumes any legal liability or responsibility for the accuracy, completeness, or usefulness of any information, apparatus, product, or process disclosed, or represents that its use would not infringe privately owned rights. Reference herein to any specific commercial product, process, or service by trade name, trademark, manufacturer, or otherwise does not necessarily constitute or imply its endorsement, recommendation, or favoring by the United States Government or any agency thereof. The views and opinions of authors expressed herein do not necessarily state or reflect those of the United States Government or any agency thereof. 


\section{DISCLAIMER}

Portions of this document may be illegible in electronic image products. Images are produced from the best available original document. 
The facilities of Argonne National Laboratory are owned by the United States Government. Under the terms of a contract (W-31-109-Eng-38) between the U. S. Department of Energy, Argonne Universities Association and The University of Chicago, the University employs the staff and operates the Laboratory in accordance with policies and programs formulated, approved and reviewed by the Association.

\section{MEMBERS OE ARGONNE UNIVERSITIES ASSOCIATION}

The University of Arizona Carnegie-Mellon University

Case Western Reserve University

The University of Chicago

University of Cincinnati

Illinois Institute of Technology

Univer sity of Illinois

Indiana University

Iowa State University

The University of Iowa
Kansas State University The University of Kansas Loyola. University

Marquette University Michigan State University The University of Michigan University of Minnesota University of Missouri Northwestern University University of Notre Dame
The Ohio State University Ohio University

The Pennsylvania State University Purdue University

Saint Louis University

Southern Illinois University The University of Texas at Austin Washington University Wayne State University The University of Wisconsin

\section{NOTICE}

This report was prepared as an account of work sponsored by the United States Government. Neither the United States nor the United States Department of Energy, nor any of their employees, nor any of their contractors, subcontractors, or their employees, makes any warranty, express or implied, or assumes any legal liability or responsibility for the accuracy, completeness or usefulness of any information, apparatus, product or process disclosed, or represents that its use would not infringe privately-owned rights. Mention of commercial products, their manufacturers, or their suppliers in this publication does not imply or connote approval or disapproval of the product by Argonne National Laboratory or the U. S. Department of Energy. 
ENERGY RESOURCES TECHNICAL TRAINING AND DEVELOPMENT PROGRAMS FOR AMERICAN INDIANS

by

Roy E. Cameron

W. Sedgefield White

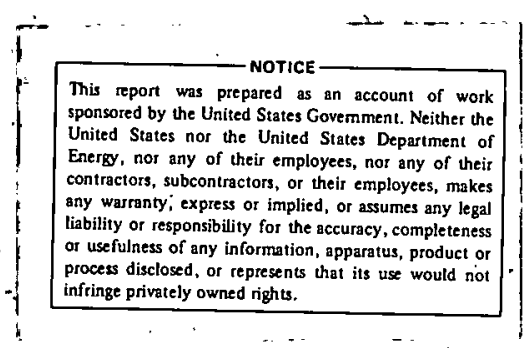

August 1978

DIVISION OF ENVIRONMENTAL IMPACT STUDIES

ARGONNE NATIONAL LABORATORY

Argonne, Illinois 60439 
CONTENTS

$\underline{\text { Page }}$

Introduction . . . . . . . . . . . . . . . . . . . 2

Program Objectives and Purpose . . . . . . . . . . . . . . 2

Goals . . . . . . . . . . . . . . . . . . . . . 3

Benefits to the Tribes ..................... . 4

Program Criteria and Approach . . . . . . . . . . . . . . 5

Course Contents......................... 6

Programs Completed Prior to 1978 .. . . . . . . . . . . . . . 7

Navajo Community College . . . . . . . . . . . . . . 7

Eastern Montana Training Program . . . . . . . . . . . . . 9

Evaluation and Results of Completed Programs . . . . . . . . . . . . . 11

Navajo Community College . . . . . . . . . . . . . . . 11

Eastern Montana Training Program . . . . . . . . . . . 12

Programs Held During Summer 1978 . . . . . . . . . . . . . . 13

Navajo Community College . . . . . . . . . . . . . . . 13

Fort Peck and Miles Community Colleges . . . . . . . . . . . . . 14

Flathead and Blackfeet Community Colleges . . . . . . . . . . 15

Future Programs . . . . . . . . . . . . . . . . . . . 17

Conclusions . . . . . . . . . . . . . . . . . . . . 19

Problem Areas . . . . . . . . . . . . . . . . . . . 20

References . . . . . . . . . . . . . . . . . . 22 


\title{
ENERGY RESOURCES TECHNICAL TRAINING AND DEVELOPMENT PROGRAMS FOR AMERICAN INDIANS
}

Roy E. Cameron and W. Sedgefield White

\begin{abstract}
Because of the energy resources located on Native American owned lands, it is pertinent that the tribes on these reservations receive information, training, and technical assistance concerning energy and the environment and the decisions that must be made about energy-resource development. In the past, attempts to enlist Indians in technical assistance programs met with little success because teaching methods seldom incorporated program planning by both tribal leaders and the technical training staff.

Several technical assistance programs given on reservations in the central and western parts of the country were conducted by Argonne National Laboratory--programs that stressed practical, onthe-job experience through lecture, laboratory and field studies. Each program was designed by $A N L$ and tribal leaders to fit the needs and concerns of a particular tribe for its environment. The individual programs met with an impressive degree of success; they also prompted several Indians to pursue this type of education further at $A N L$ and local Indian community colleges and to obtain funds for energy projects.

Despite the positive feedback, several difficulties were encountered. Among them are the necessity to continually modify the programs to fit diverse tribal needs, to diminish politically motivated interference, and to increase portions of the funding to involve more Native Americans.
\end{abstract}


INTRODUCTION

During the development of the Argonne National Laboratory (ANL) Land Reclamation Program, it berame increasingly evident that Native American tribes needed information, training, and assistance in energy extraction and land reclamation. Since the tribes have energy resources on their lands, decision-makers needed education in energy resources and the impacts on the environment from energy extraction and development. Tribal. officials also needed the means of evaluating environmental impacts, cost effective land reclamation technologies, and land use alternatives and management practices. To meet these needs, funding for technical assistance programs for the tribes was obtained from the former Energy Research and Development Administration (ERDA), and subsequently from the Department of Energy (DOE).

PROGRAM OBJECTIVES AND PURPOSE.

The programs now being conducted on the reservations are an attempt to partially meet the needs and concerns of American Indians regarding the potential and/or ongoing energy extraction and development on their lands and the surrounding areas. The intent is to provide an introduction to their energy sources and natural resources. These programs address energy development, conservation and/or preservation, assessment and monitoring, reclamation, legal issues, and other aspects of energy resource development. The programs are designed to provide on-the-job experience and instruction in practical theory on energy and ecological relationships. In addition, the programs introduce American Indian students, as well as tribal and technical personnel, to energy technologies and environmental sciences. This exposure will help to 
motivate individuals to obtain further education and training in these fields; and thus provide tribal leaders with decision-makers who have had indispensable training and education in energy and environmental subjects.

GOALS

First, several goals were designed so the purpose and objectives of the efforts could be reached. These goals are:

1. To develop educational training and technical assistance programs to meet tribal and individual needs.

2. To consult with tribal councils, tribal organizational representatives and others so that tribal needs and concerns regarding an energy resource development and training program can be included in the program.

3. To develop a program based upon discussions with tribal groups and tailored to the tribal physiographical and cultural setting.

4. To work with tribal educational personnel, manpower commissions, and other tribal representatives to develop, schedule, and coordinate the programs.

5. To provide qualified instructors, training, and technical assistance to implement the training programs.

6. To modify, enlarge and/or continue to provide future instruction and training to meet changing tribal needs and concerns as required. 
BENEFITS TO THE TRIBES

The design of the technical training program includes the following benefits to the tribes:

1. An opportunity to understand the methods and means of identifying energy and natural resources, their extraction, and development.

2. An opportunity for understanding energy, environmental, and natural resource conservation, protection, utilization, monitoring, and assessment.

3. Introductive training for Native Americans in methods of measuring, monitoring, evaluating, and assessing environmental impacts and standards.

4. Basic training in cost-effective land reclamation practices, land usage, and land use alternatives.

$$
\text { n. r }
$$

5. Inducement and encouragement for motivating students to undertake careers in energy-and environmental-related occupations.

6. A means for further training and education of tribal supervisory and technical personnel.

7. A mechanism for encouraging further training and education to include broader problem areas and other disciplines, leading to an associate (2-year) college degree. 
8. Important background, knowledge, and experience for decisions involving energy resources, extraction, development, and utilization.

9. Practical experience in mining, milling, and drilling operations, reclamation technologies, and alternatives for decisions and policies involving tribal lands and resources.

10. Involvement of the tribes more directly in the mainstream of national energy needs, problems and plans, and provide a means of directly contributing solutions to these problems from up-to-date, first-hand knowledge and experience.

PROGRAM CRITERIA AND APPROACH

As intended, education and training are coordinated with tribal concerns as expressed by tribal representatives and are devised to meet tribal needs. The programs consist of lecture, laboratory, and field work; however, they are heavily oriented toward practical use of laboratory instruments, as well as field observations and evaluations. Bașic theory is minimized except as it applies to "real world" situations and applications.

The level of instruction is intended to meet tribal needs; it is modified to meet student educational background and motivation. Course criteria and student selection is determined by each tribal education group and is then reviewed by tribal community college coordinators and ANL program directors. An educational level equivalent to a high school degree is generally considered as a minimum requirement. Course work or knowledge of high school mathematics, 
English language comprehension, reading and writing ability, and science are desirable. A math review is conducted at the beginning of each program.

COURSE CONTENTS

Each program includes a review of the ongoing or potential energy development within the reservation. Th1s review addresses past, present, and future impacts, and subsequent potential or actual effectiveness of reclamation as practiced by energy development companies. Classroom and laboratory studies are combined with frequent field investigations and visits to mining, milling, drilling, construction, power plant, dam and reclamation sites. Basically, the courses include terrestrial and aquatic ecology, field ecological sampling techniques; collection, presentation, and interpretation of ecological data; geology, hydrology, and geochemistry; water quality and water rights; air quality and monitoring; soil science-plant relationships; agronomy, range and wildlife management; forestry, grasslands, and revegetation techniques; visits to coal mines, oil drilling sites, and other energy extraction sites; environmentally stressed areas; and discussions on energy development and land-use.

It should be noted, that courses do vary depending on the needs, concerns, and environmental setting of each reservation.

PROGRAMS COMPLETED PRIOR TO 1978

Navajo Community College

The first program was undertaken for six weeks during the summer of 1976 
at Navajo Community College (NCC), Tsaile, in northeastern Arizona. The program content was established after discussions with members of the Navajo and Hopi tribes, and suggestions from academic and coal company representatives.

Instruction for the Navajo/Hopi program was provided by 12 scientists and engineers of the Land Reclamation and Coal Extraction Programs of ANL's Energy and Environmental Systems Division (EES) and Environmental Impact Studies Division (EIS). Coordination and assistance were provided by personnel of NCC and also the University of Arizona's Office of Arid Lands.

Subject matter included geology, civil engineering, hydrology, geochemistry, soil science, microbiology, aquatic ecology and chemistry, statistics--data collection and interpretation, range management, wildlife ecology, and agronomy. Basic principles of ecology, natural resources, energy development, land-use, and reclamation were emphasized in lectures. Laboratory demonstrations and experience in analytical methods were provided along with practical field work relevant to the natural environment of the reservation. Field work was conducted entirely on reservation lands and also included informative visits to Utah International's Navajo Mine, Peabody Coal Company.'s Black Mesa Mine, and Pittsburg and Midway's McKinley Mine. All of these mines are actively engaged in coal strip-mine extraction and reclamation projects. Coal Company reclamation engineers cooperated by providing information on mining and reclamation during all-day visits to these mines; one coal mine employee also took part in a portion of the training program.

Six Hopis from the Hopi Manpower Commission and four Navajos from the Navajo Natural Resources Division completed the course of study and earned six 
units of college credit. The graduation ceremony, with presentation of certificates of course completion, was attended by representatives of ERDA, ANL, NCC, University of Arizona Office of Arid Lands, Navajo and Hopi Tribal Organizations, and coal companies. Immedlately following the graduation exercises, a preliminary planning session was held with comments and suggestions provided by about 20 of the representatives present. During this planning session, the programs' effectiveness was evaluated in anticipation of future programs. There was consideration shown for the need to develop a two-year curriculum at NCC in energy resources and environmental technology.

A second evaluation and preplanning meeting was held at Window Rock, Arizona (Navajo Nation Capital). The evaluation was based upon a final report received from Navajo Community College ${ }^{l}$. In addition, a paper was presented primarily dealing with student evaluations of the courses, their structure and content, the effectiveness of instruction, and degree of proficiency of the instructors. It was agreed that the program was effective and the dropout rate phenomenally low because the training met individual (and tribal) needs. The instruction was considered to be practical and applied, the subject matter was field-oriented, and the program supplied information and methods which the students might be able to apply to their jobs, i.e., Hopi Office of Manpower Programs, Navajo Environmental Protection Commission, and Navajo Office of Minerals Development. The representatives at the meeting felt that the high motivation, dedication, and interest levels of all involved in the program were contributing factors to the success and effectiveness of the program.

A statement by Larry Isaac, a Native American (Navajo) and former VicePresident of the Navajo Community College, summed up the NCC opinion of the 
ANL, ERDA funded effort:

\begin{abstract}
"The moral and financial support received from ANL and ERDA was unique. There has been too much lip service ending up with documentation in Washington, D.C. ANL is the only agency that is literally neutral in asking what the people want and need. What ANL and ERDA has to offer is legitiamte for our needs and wants. NCC stands ready to become involved in the long-range planning of this program for ANL and ERDA."
\end{abstract}

Consequently, the Navajo-Hopi program, with some modifications, has provided the basis for future programs. In 1977, another proposal was written and submitted to ERDA. Funding was obtained to undertake a second ten-week program at NCC. It included Hopis, Navajos, and Zunis. The program was broadened in scope to include uranium and forestry. It not only involved instructors from ANL, but also from universities and colleges, state/federal agencies, tribal organizations, and energy extraction companies. The program was conducted intermittently between April and September for a total of ten weeks: The intermittent schedule allowed students to obtain job-release time over the tenure of the program.

\title{
Eastern Montana Training Program
}

Following the completion of the Navajo-Hopi Training Program, the Land Reclamation Program was contacted by the Coal Research Office, Crow Tribe, Crow Agency, Montana. The Crows and other tribes located near active mining operations in Montana expressed an interest for a similar program. Westmoreland Resources is mining coal at the Absaloka Mine on Crow-leased land at Sarpy Creek, east of Hardin, Montana and the Northern Cheyennes are concerned about coal extraction activities and impacts surrounding their reservation; especially 
air quality and how the designated Class I air standard affects their reservation. The Assiniboine/Sioux at the Fort Peck Reservation in northeastern Montana are considering impending consequences of mining of lignite and subbituminous coal on their lands (between 1951 and 1972, more than 24 million barrels of oil also were produced on their land, and potash mining is of considerable concern).

Visits were made to Crow Agency, and discussions were held with personnel of the Crow Council, Office of Coal Research, Minerals Commission, Education Commisston, and other representatives of tribal programs. A decision was readily reached that the Crow Tribe needed an energy resource and land reclamation program, to include environmental impact assessment and monitoring relative to mining and reclamation. The Crow Central Education Commission was given tribal sanction to work with ANL. It was stressed that the training should be conducted on tribal lands and be applicable to tribal needs. It also was suggested that the Northern Cheyenne and the Assiniboine/Sioux Tribes at Fort Peck be contacted. Visits were made to the Northern Cheyenne Reservation and discussions were held at Lame Deer. It was suggested that several students from the Northern Cheyenne Reservation could take part in the program after a presentation was made to their tribal council and their interest was determined. The Assiniboine/Sioux Deputy Director of the Office of Native Americans was contacted and a positive response was obtained from the Assiniboine/Sioux representative and the Fort Peck Tribal Council.

A six-week program was developed and 20 students from the three reservations were enrolled in the program. Instructors were provided primarily from ANL, but also included consultants from Montana State University, South Dakota 
School of Mines, State/Federal agencies, and tribal organizations. All 20 Indian students who took part in the summer program completed it, earning eight units of college credit from Miles Community College, Miles City, Montana.

EVALUATION AND RESULTS OF COMPLETED PROGRAMS

Navajo Community College

The second year's program at NCC was conducted as "workshops" for those Indians who were already employed by industry, or the tribal or federal governments in positions dealing with resources--environmental protection in relation to energy development, minerals development, land reclamation, forestry, wildlife and range management, parks and recreation, and tribal planning. The program's purpose was to assist these individuals in developing further skills and knowledge in energy/environmental techniques and concepts. The workshops were conducted for ten week-1ong sessions between April and September, 1977, to allow individuals and their supervisors to plan for their normal work. The 126 participants were employees of Peabody Coal Company, Navajo Fish \& Wildlife, : Navajo Forestry, Navajo Parks \& Recreation, Navajo Environmental Protection Commission, Navajo Range Resources, Navajo Livestock \& Extension, Navajo Natural Resources Training, Navajo Minerals Development, Hopi Tribal Planning, Hopi Health Services, Hopi Range \& Livestock, and Zuni Fish \& Wildlife.

The number of students in the workshops varied from 3 to 20 . The workshops; on applied fields (range management, wildlife management, parks and recreation management, and forestry) tended to have a higher enrollment than those presenting more basic scientific disciplines, such as geology. Supervisors of 
the various departments in which the participants were employed said the workshops were useful, needed, and should be continued. They also said that it would be helpful if future workshops could be spread through the year so that more employees could be available for training. The one shortcoming of the separate workshops was the lack of continuity in training due to the participants' inability to attend successive workshops and, therefore, build on the background presented in earlier sessions; however, this was unavoidable.

In conclusion, even though the workshops were considered successful for their intended purposes, it is believed that if individuals with backgrounds in modern environmental science and technical skills are to be obtained, a complete, technician-level-oriented academic program must be developed to attract and train Native Americans on a full-time basis. NCC should move toward the development of such an educational program. ${ }^{2}$

\section{Eastern Montana Training Program}

Miles Community College evaluated the summer program held at Crow Agency in Eastern Montana. The evaluation indicated that there is a continued need for the program and that the continuous development of natural resources (coa1) near reservations requires the need for knowledgeable and skilled Native American engineers, scientists, and technicians. ${ }^{3}$ A Crow Central Education Commission survey of Indian students attending college in Montana showed that all of the Indian students were enrolled in humanity areas.

In summary, it was determined that the Crow, Northern Cheyenne, Assiniboine/ Sioux program provided an enhanced awareness of energy related problems. The 
onsite field trips helped to bring theory into reality, making program content of immediate and tangible value to the participants. Since the program was intended to give the students tools to seek the answers for their own reservations and to broaden their horizons, the program met the desired goals.

Subsequently, the Crow and Fort Peck Reservations sent four of their students employed in the energy development/reclamation and monitoring fields to further participate in the Affirmative Action Program at ANL to receive additional training under the tutelage of individual scientists. Two Northern Cheyenne students received additional training under this program in methods of soil, air and water analyses. Several of the students indicated that they may take additional course work in specific technical areas. After the summer training program, four students from the Fort Peck Reservation formed a Tribal Environmental and Energy Office. Direct spin-offs of the program include a possible program utilizing satellites for education video presentations and further cooperative educational ventures among the participants. Indirect spin-offs include additional work with area community colleges and university units to provide technical course work on reservations.

PROGRAMS HELD DURING SUMMER 1978

Navajo Community College

This summer a ten-week program was conducted in anticipation of developing a two-year, technician-level Energy and Environmental Technology training program. The ten-week program in environmental technology was offered at NCC. The anticipated two-year program, which will lead to an Associate of Applied 
Science (AAS) degree, can provide individuals with the academic background and technical skills for employment as environmental, energy, mineral, and natural resource technicians.

The first five weeks of the summer, ten-week program--June 5 through July 7--were spent at Tsaile in classroom-laboratory work and field trips to introduce students to basic concepts and skills in environmental science. The remaining five weeks--July 10 through August 11--were spent in ful1-time positions for students with industry or government where they gained practical, on-the-job experience in applying environmental concepts to current problems and studies in such fields as forestry, resource management, land reclamation and environmental protection. CETA provided student stipends for the program.

Student selection was based on educational background, recommendations, and an expressed interest in continuing toward a career in energy resources and environmental technology. Preference was given to applicants just completing high school or with no more than one year of college. Applicants were primarily Hopi, Navajo, and Sioux. The class size was limited to 20 students. At least twelve of the students will continue at NCC in fall, 1978, in the Energy and Environmental Technology Program and others will continue in related fields at other institutions.

\section{Fort Peck and Miles Community Colleges}

For summer, 1978, the program in Eastern Montana was shifted from Crow Agency to the Fort Peck Reservation at Poplar, Montana, to accommodate the needs and participation of the Fort Peck Tribes, those at Rocky Boys, Fort 
Belknap and Fort Berthold, North Dakota. The program developed with tribal council and organizational representatives was a "follow-up" of the program previously conducted at Crow Agency. It was also in consideration of the impending lignite development at Fort Peck and Fort Berthold and impacts of coal strip mining, uranium, uranium and postash mining, oil drilling, transmission lines, environmental stress and pollution of alluvial valley floors.

Subjects included basic ecology and math review, and terrestrial impacts of energy and resource development. Field trips included visits to appropriate energy and/or mine and material resources sites.

The program was coordinated with Miles Community College, which shared responsibilities with the Fort Peck Community College at Poplar, Montana. Consultation included the Fort Peck Tribe's Environmental and Energy Educational Office.

This program, however, was not completed as scheduled, because of difficulties in communication between and'within the expected participating tribes and the prevailing political atmosphere of several non-Fort Peck tribes. The program was moved to the Flathead Reservation where the remaining Fort Peck program participants were enrolled.

\section{Flathead and Blackfeet Community Colleges}

- The coordinator for the program at Crow Agency contacted representatives of the Flathead and Blackfeet reservations and suggested to ANL that an energy resources and environmental program was needed by Salish/Kootenai and Blackfeet 
tribes. Timing, funding, and personnel limitations did not permit program development for these Western Montana tribes until the latter part of 1977. During the later months of the year, when conditions were better for instituting a program, trips were made to Western Montana to discuss the needs and development of a program for the Western Montana tribes and to determine the interest of joint funding by the old West Regional Commission.

Two trips were made to Flathead Valley Community College, Kal1spe11, Montana, north of the Flathead Reservation, and to the Blackfeet Reservation, Browning, for planning talks with representatives from Flathead Valley Community College, Blackfeet Community College, the Flathead Reservation and Blackfeet Reservation. During these meetings and subsequent correspondence, the tribal needs were identified and topics to be covered in the training programs were suggested. It was decided the program would be conducted during a six-week period between June 5 and July $14 ; 1978$.

The Old West Regional Commission agreed to jointly fund the program with DOE. As suggested by the local coordinators from each reservation organization, the program consisted of information regarding energy development on their lands, the impacts and implications of energy extraction and development, the use of resources associated with energy resources, and reclamation and recovery of disturbed land. The program was intended to provide basic information on energy resources and ecology of the reservations. It also would motivate individuals to continue their education and training in the energy and environmental sciences so they could better aid tribal leaders in the decision-making process. During the six-week period, ten field trips included visits to coal, 
oil drilling, hydroelectric, and other sites. Approximately ten students were sponsored by both Salish-Kootenai Community Cọllege and Blackfeet Communịty College.

Topics discussed included the impacts of transmission lines, terrestrial impacts of forestry management, recreational area development, development of alternative energy sources (solar, geothermal, and wind power generation), and impacts of hydroelectric dams.

Flathead Valley Community College functioned in the role of college coordination, and local coordinators were provided by each tribal community college. ANL had overall management responsibilițy for the program as well as primary responsibility for its instruction and development.

FUTURE PROGRAMS

All successive programs will be based upon the evaluation and need for programs conducted in previous areas, the needs and/or demands for programs in other reservations, and the availability of funds from DOE and other agencies and organizations interested in joint funding of Indian training and technical assistance programs. All or none of the successive programs may be varied, enlarged, or reduced. Opportunities for additional programs are explored as contacts are made either to ANL by other tribes, or following suggestions from other sources: Contacțs have been made with Northern Cheyenne, Arapahoe, Shoshone, Spokane, Piute, Menominee, Puyallup, and Penobscot Tribes, in addition to Native Associations in Alaska, especially Cook Inlet. It also has been suggested that contact be made with the Mountain and Southern Ute, Pueblos 
(Acoma, Laguna and Zuni), and Western and Eastern Washington Tribes. Some of the presently nonparticipating tribes are considering the commitment of CETA funds to enable them to take part in the programs.

In addition, tribal-related organizations have contacted ANL in regards to participating in the programs. These include the Indian Lignite Manpower Program of the United Tribes Educational Technical Center, Bismark, North Dakota, and the Bureau of Indian Affairs (B.I.A.) Southwestern Indian Polytechnic Institute, Albuquerque, New Mexico.

Newly-formed Indian Community Colleges have benefitted from past programs. Navajo Community College has assisted the tribal community and tribal supervisory and technical personnel through the workshop-type programs that have been conducted over the past two summers. As mentioned, past programs held at NCC are helping to lay the foundation for a two-year, degreed work study program in energy and environmental sciences. Blackfeet, Salish-Kootenai, Fort Peck, Flathead Valley, and Miles Community Colleges are coordinating colleges for this year's programs. The programs could be undertaken through these colleges in 1979 after the 1978 programs are reviewed and evaluated.

Currently, there are efforts to develop and implement assessment and technical assistance workshop-seminars on uranium mining, milling, monitoring, reclamation, and related subjects, such as health hazards. These workshopseminars could be coordinated with Indian uranium and nuclear fuel cycle symposia. Little attention has been devoted to various factors of uranium 
development on Indian lands, despite the estimate of their having 40 to $90 \%$ of the uranium resources. Education and training are direly needed in these areas.

Studento, tribal organizational personnel, and commissions are continuing to suggest the development of a basic syllabus on energy resources and related environmental problems which are applicable to Indian reservations and interests. The syllabus should include basic principles, along with practical laboratory experiments and field tests. As funds are made available, the syllabus will be developed. The DOE University Programs Office has offered to print and distribute the syllabus and it will be used in future programs.

CONCLUSIONS

The Indian Training and technical assistance programs began by ERDA and the successive DOE are an initial limited attempt to meet some of the technical needs of American Indian tribes possessing energy resources, and their concerns over conflicting desires for energy development/economic improvement and environmental/cultural preservation. These technical programs have met with a measure of success, despite the disadvantages and adverse circumstances which have been encountered by previous attempts at Indian education, training, and technical assistance programs. The success of these programs can be attributed to tribal political and organizational backing and interest; competent and motivated Indian educators as coordinators; the screening process of tribal educational entities to select the most qualified individual candidates who will benefit not only individually from the training, but who will advance tribal goals; motivated and interested students, especially those who see the 
job relationship and potential of the training; knowledgeable instructors who are both personally interested and motivated to spend the necessary time with the students; provision and undertaking of up-to-date "real-world", practical field and laboratory experience; demonstration of the relevance of the instruction to the reservation environment; and locating the instruction entirely on the reservation, or with applicable field trips to environs adjacent to Indian 1ands.

Finally, planning and evaluation sessions are undertaken prior to the programs and following their completion, to obtain the recommendations of tribal, academic, governmental, and industrial personnel before developing or repeating a program.

PROBLEM AREAS

Several "problem areas" have been identified during the tenure of the program. One is the persistent exclusion of student need for stipend and dependency allowances in the overall funding. It must be recognized that many Indian students must support themselves and their families for the tenure of the program, resulting in the denial of participation in the program to a number of students. Support for student stipends from other organizations is variable. Assistance from the Bureau of Indian Affairs (B.I.A) is locallydependent, ranging from whole-hearted participation and complete cooperation to the practice of administrative, bureaucratic, and "red-tape" obstacles. CETA funds can be used by the tribes if they meet CETA criteria for job training and placement. Supplementary funds, such as those provided by the 
Old West Regional Commission, greatly help to undertake and extend the programs, such as for the:Blackfeet and Salish/Kootenai tribes.

Attempts are made to meet with and make presentations to tribal councils. Such meetings require preliminary discussinns with tribul members and representatives. Scheduling and rescheduling, visits and revisits are made for the presentations. Resolutions whether or not to undertake the program may be politically determined. Designated tribal appointees may or may not assist the program, but tribal educational committee members who are usually approached first via introduction by other tribal educational personnel has proved quite successful. Working with cooperative and motivated local tribal educators is necessary to the success of a particular program.

It has been found that considerable expense and time are involved in the initial stages of contacting the tribes to undertake discussions on the possible development and 1mplementation of programs. Time-involved communications and contacts also must be continued during the entire program. It has been found essential that information about the program be kept flowing and freely accessible to all interested parties. This, too, is one of the factors of success for the programs.

Additional problems are encountered in attempts to hold programs for tribes having needs for the program, but having small membership. Attempts to include them in larger programs or forming a coalition of smaller tribes in a larger program, must be considered. Long-standing intertribal animosities are not easily overcome regardless of common goals, needs, concerns, and problems. 
Longterm "feedbeck" also must be obtained for each program, especially in what has happened to each student, and how each student or the tribe has benefited. from a particular program. This will be undertaken, primarily through the participating colleges.

\section{References}

1. Matlock, J. (ed.), 1976. Final Report of a Pilot Training Program in Principles of Land Reclamation Technology, July 12 - August 20, 1976, in cooperation with ANL of the U.S. ERDA and Office of Arid Lands of the University of Arizona, Navajo Community College, Tsaile, Arizona, 13 pp. and Appendix A-C.

2. Matlock, J., and F. Beauvais, 1978. Final Evaluation Report of Workshops in Energy and Environmental Technology, April 18 - Sept. 16, 1977, Navajo Community College, $10 \mathrm{pp}$. and Table 1 and Appendix.

3. Joyce, J., and F. McKee, 1977. Final Report of a Training Program on Energy Resources, Environment, and Land Reclamation, June 20 - August 1, 1977, in cooperation with ANL and Crow Central Education Commission, Miles Community College, Miles City, Montana, 12 pp. and Appendix.

\section{Brochures}

1. "Montana Indian Training Program," Energy Resources Training and Development, ANL-EIS, 6 pp., 1978.

2. "Southwest Indian Training Program," Energy Resources Training and Development, ANL-EIS, 6 pp., 1978. 